\title{
Specification
}

Project No. 23841

\section{AGR-5/6/7 Fuel Fabrication Feedstock Chemical Purity Specifications}

The INL is a

U.S. Department of Energy National Laboratory operated by

Battelle Energy Alliance

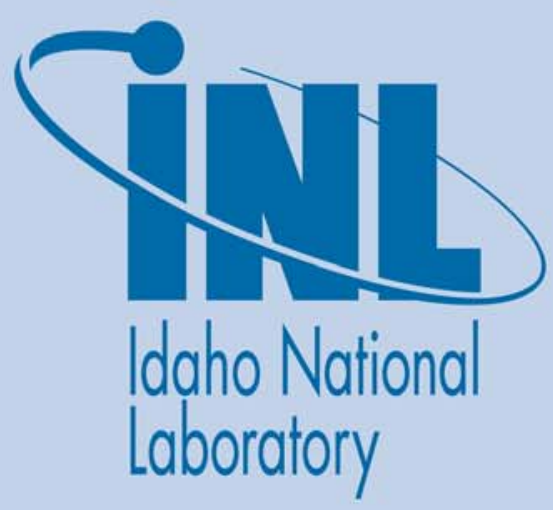

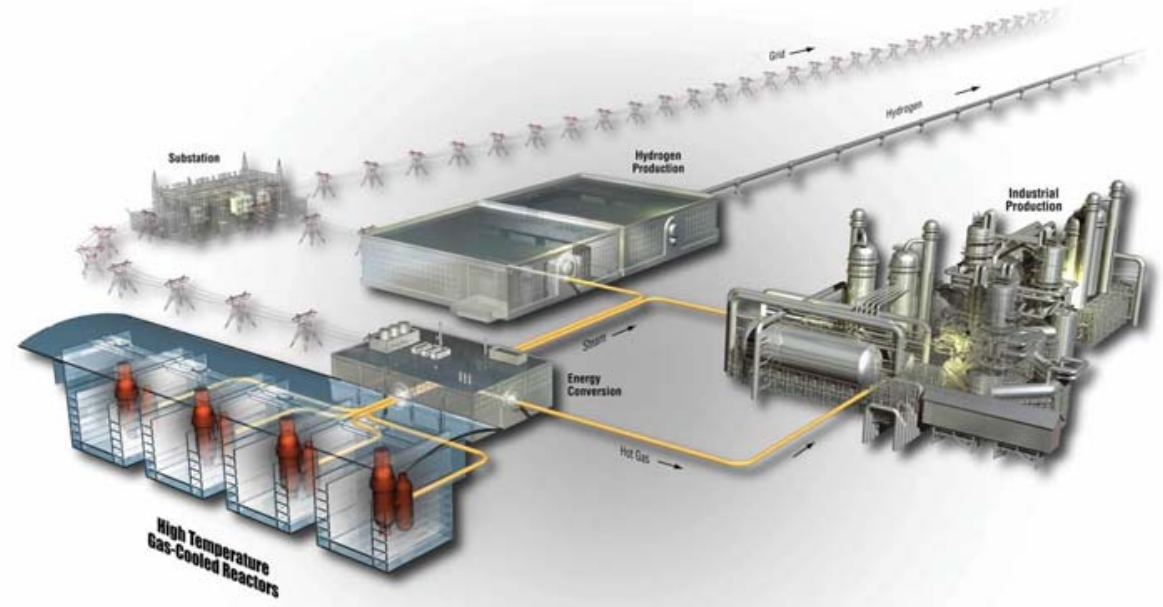


Idaho National Laboratory

\begin{tabular}{|c|lll|}
\hline $\begin{array}{c}\text { AGR-5/6/7 FUEL FABRICATION } \\
\text { FEEDSTOCK CHEMICAL PURITY }\end{array}$ & Identifier: & \multicolumn{2}{l|}{ SPC-1363 } \\
Revision: & 5 & Page: 2 of 12 \\
SPECIFICATION & Effective Date: & $03 / 14 / 2017$ & eCR Number: 648775 \\
\hline INL ART TDO Program & Specification (SPC) & & \\
\hline
\end{tabular}

\begin{tabular}{|c|c|c|c|}
\hline \multicolumn{3}{|c|}{ SIGNATURES } \\
\hline $\begin{array}{c}\text { Signature and } \\
\text { Typed or Printed Name }\end{array}$ & $\begin{array}{c}\text { Signature } \\
\text { Code }\end{array}$ & $\begin{array}{c}\text { Date } \\
(\mathrm{mm} / \mathrm{dd} / \mathrm{yyyy})\end{array}$ & Organization/Discipline \\
\hline
\end{tabular}

\begin{tabular}{|l|l|l|l|}
\hline Nutilashall & P & $03 / 14 / 2017$ & $\begin{array}{l}\text { C020/INL ART TDO TRISO Fuel } \\
\text { Fabrication Technical Lead }\end{array}$ \\
\hline
\end{tabular}

Douglas W. Marshall

\begin{tabular}{|c|c|c|c|}
\hline & $\mathrm{A}$ & $3 / 14 \mid 17$ & $\begin{array}{l}\text { C020/INL ART TDO TRISO Fuel } \\
\text { Director }\end{array}$ \\
\hline \multicolumn{4}{|l|}{ Paul A. Demkowicz } \\
\hline & A & $3 / 14 / 2019$ & $\begin{array}{l}\text { C020/INL ART TDO Program } \\
\text { Manager }\end{array}$ \\
\hline
\end{tabular}

Travis R. Mitchell

\begin{tabular}{|l|l|l|l|}
\hline hy 1 Shaye & C & $3 / 14 / 2017$ & H330/INL Quality Engineer \\
\hline Michelle T. Sharp & C & \\
\hline
\end{tabular}

P For Preparer of the document.

A For Approval: This is for non-owner approvals that may be required as directed by a given program or project. This signature may not be applicable for all uses of this form.

C For documented review and concurrence. 
AGR-5/6/7 FUEL FABRICATION FEEDSTOCK CHEMICAL PURITY SPECIFICATION
Identifier: $\quad$ SPC-1363

Revision: $\quad 5$

Effective Date: 03/14/2017

\section{CONTENTS}

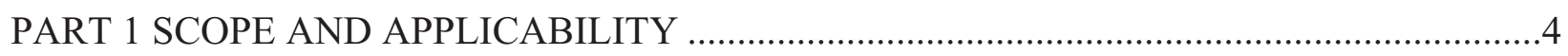

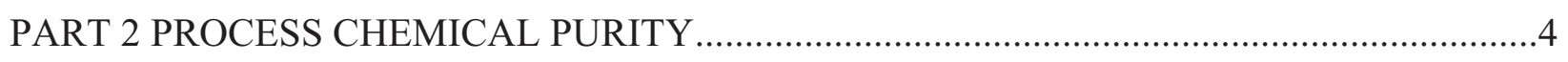

2.01 Fuel Kernel Forming and Sintering .........................................................................

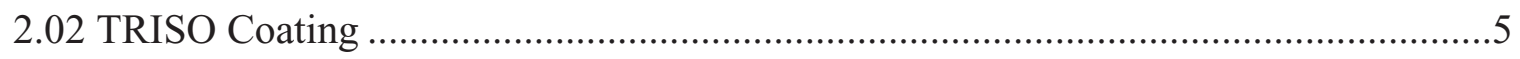

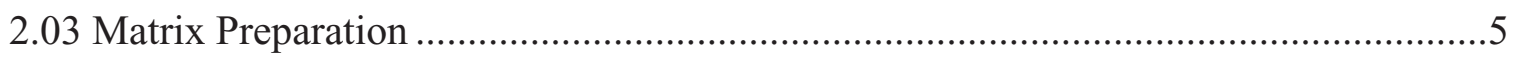

2.04 Overcoating and Compacting ...................................................................................

2.05 Carbonization and Heat Treatment .........................................................................

PART 3 CHEMICAL PURITY VERIFICATION AND EXCEPTIONS ........................................

3.01 Chemical Certifications ………………………….............................................

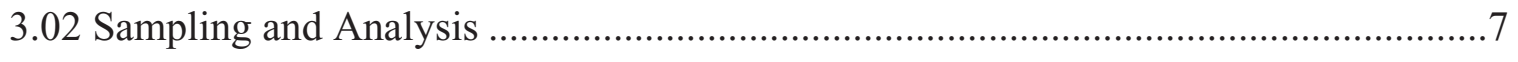

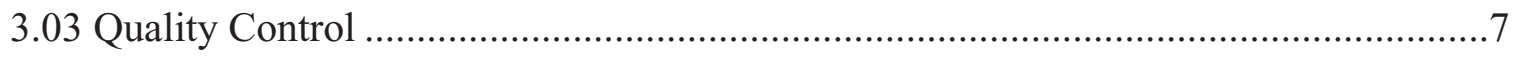

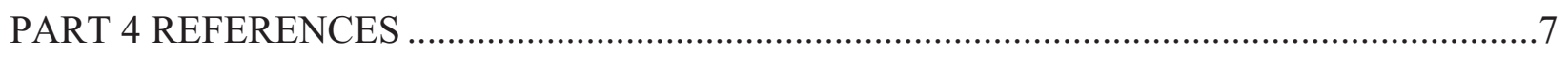

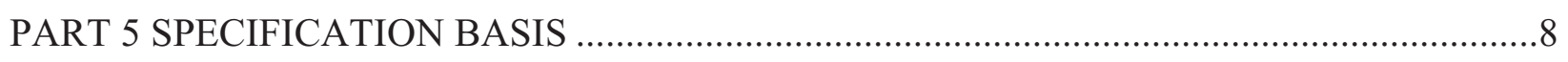

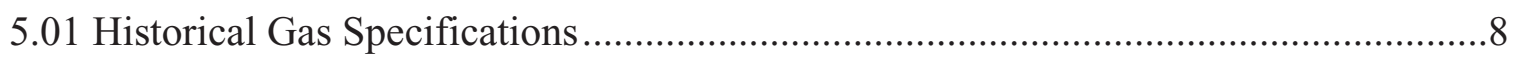

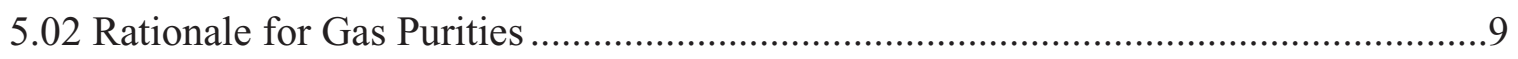

5.03 Rationale for Liquid Purity .....................................................................................11 


\begin{tabular}{|c|lll|}
\hline AGR-5/6/7 FUEL FABRICATION & Identifier: & SPC-1363 & \\
FEEDSTOCK CHEMICAL PURITY & Revision: & 5 & \\
SPECIFICATION & Effective Date: & $03 / 14 / 2017$ & Page: 4 of 12 \\
\hline
\end{tabular}

\section{PART 1 SCOPE AND APPLICABILITY}

This specification has been prepared to provide fuel fabricators with minimum chemical purity specifications intended to ensure that fuel components have consistent properties and that impurity levels in the as-fabricated fuel are sufficiently low to minimize in-pile TRISO particle failures and to assure fission product retention. Process chemical purity specifications are given for the following processes:

- Kernel forming and sintering

- $\quad$ TRISO particle coating

- Matrix preparation

- TRISO overcoating

- Compact carbonization and heat treatment.

\section{PART 2 PROCESS CHEMICAL PURITY}

\subsection{Fuel Kernel Forming and Sintering}

\section{A. Chemical additives, Washes, and Aging Solutions}

All chemical additives, employed in the forming broth or in the washing and aging of gelatinous fuel spheres shall meet the chemical manufacturer reagent grade specifications except as otherwise specified in this subpart.

\section{B. Carbon Black}

The carbon black shall be the Cabot Corporation TPX 101 or approved equivalent.

\section{Carbon Monoxide}

Carbon monoxide shall be ultra-high purity (UHP) and meeting the following specifications:

$\begin{array}{ll}\mathrm{CO} & \geq 99.9 \% \mathrm{v} / \mathrm{v} \\ \mathrm{CO}_{2} & \leq 25 \mathrm{ppmv} \\ \mathrm{H}_{2} \mathrm{O} & \left.\leq 5 \mathrm{ppmv} \text { (or } \leq-65.4^{\circ} \mathrm{C} \text { dew pt. }\right) \\ \mathrm{N}_{2} & \leq 900 \mathrm{ppmv} \\ \mathrm{O}_{2} & \leq 10 \mathrm{ppmv}\end{array}$

\section{Dispersants and Surfactants}

\section{Not specified}

\section{E. Forming Fluid}

Not specified.

\section{F. Hydrogen ${ }^{\mathrm{a}}$}

Hydrogen shall meet the following limits:

$\begin{array}{ll}\mathrm{H}_{2} & \geq 99.95 \% \mathrm{v} / \mathrm{v} \\ \mathrm{O}_{2} & \leq 10 \mathrm{ppmv} \\ \mathrm{H}_{2} \mathrm{O} & \leq 7.8 \mathrm{ppmv}\left(\text { or } \leq-62.2^{\circ} \mathrm{C} \text { dew pt. }\right)\end{array}$




\begin{tabular}{|c|lll|}
\hline AGR-5/6/7 FUEL FABRICATION & Identifier: & SPC-1363 & \\
FEEDSTOCK CHEMICAL PURITY & Revision: & 5 & \\
SPECIFICATION & Effective Date: & $03 / 14 / 2017$ & Page: 5 of 12 \\
\hline
\end{tabular}

\section{G. Water}

Water purity shall meet the following limits (derived from ASTM D1193-06 Type I reagent water):

Chloride $\quad \leq 1 \mu \mathrm{g} / \mathrm{L}$

Conductivity $\leq 0.0555 \mu \mathrm{S} / \mathrm{cm}$

or

Resistivity $\quad \geq 18 \mathrm{M} \Omega \cdot \mathrm{cm}$

\subsection{TRISO Coating}

H. Acetylene $\left(\mathrm{C}_{2} \mathrm{H}_{2}\right)$

Acetylene shall meet the following limits (derived from CGA G-1.1 (R2010) Grade H acetylene) on a solvent-free basis:

$\mathrm{C}_{2} \mathrm{H}_{2} \quad \geq 99.6 \% \mathrm{v} / \mathrm{v}$

$\mathrm{H}_{2} \mathrm{~S} \leq 25 \mathrm{ppmv}$

$\mathrm{PH}_{3} \leq 15 \mathrm{ppmv}$

I. $\quad \operatorname{Argon}^{\mathrm{b}}$

Argon shall meet the following limits:

Ar $\geq 99.995 \% \mathrm{v} / \mathrm{v}$

$\mathrm{O}_{2} \leq 50 \mathrm{ppmv}$

$\mathrm{H}_{2} \mathrm{O} \leq 23.6$ ppmv (or $\leq-54^{\circ} \mathrm{C}$ dew pt.)

J. Hydrogena

Hydrogen shall meet the following limits:

$\mathrm{H}_{2} \quad \geq 99.95 \% \mathrm{v} / \mathrm{v}$

$\mathrm{O}_{2} \leq 10 \mathrm{ppmv}$

$\mathrm{H}_{2} \mathrm{O} \leq 7.8$ ppmv (or $\leq-62.2^{\circ} \mathrm{C}$ dew pt.)

K. Methyltrichlorosilane (MTS, CH3SiCl3)

MTS shall meet the following limits:

$\mathrm{CH}_{3} \mathrm{SiCl}_{3} \quad \geq 98.5 \% \mathrm{wt}$

Color Colorless

Raman or infrared spectrum Conformal to MTS spectra for the specified purity

L. Propylene $\left(\mathrm{C}_{3} \mathrm{H}_{6}\right)$

Propylene shall be polymer grade and $\geq 99.0 \% \mathrm{v} / \mathrm{v} \mathrm{C}_{3} \mathrm{H}_{6}$.

\subsection{Matrix Preparation}

\section{A. Graphite, Natural Flake}

High purity, non-intumescent (non-expanding), natural flake graphite shall be used; such as Asbury 3482 or approved alternate. 


\begin{tabular}{|c|lll|}
\hline AGR-5/6/7 FUEL FABRICATION & Identifier: & SPC-1363 & \\
FEEDSTOCK CHEMICAL PURITY & Revision: & 5 & \\
SPECIFICATION & Effective Date: & $03 / 14 / 2017$ & Page: 6 of 12 \\
\hline
\end{tabular}

B. Graphite, Synthetic

\section{Impurity \\ Mean $\mathrm{DF}_{i}$

\begin{abstract}
25\% PF Max.
Concentration (ppmw)
\end{abstract}

Al

$\mathrm{Ca}$

$\mathrm{Co}$

$\mathrm{Cr}$

$\mathrm{Fe}$

$\mathrm{Mn}$

$\mathrm{Ni}$

$\mathrm{Ti}+\mathrm{V}$

4.2
1.0
50.0
14.4
7.9
200.0
14.8
1.1

1.0

50.0

14.4

7.9

14.8

1.1
47

10

573

164

44

2293

169

60

\author{
40\% PF Max. \\ Impurity \\ Concentration \\ (ppmw)
}

60

13

729

209

56

2916

215

76

\subsection{Overcoating and Compacting}

A. Mold Release Compound

Assuming that no more than $0.04 \mathrm{mg}$ of mold release compound is used per compact, the Michelman Michem ${ }^{\circledR}$ Emulsion 52137 or approved alternate shall meet the following impurity specifications:
Al $<75$ ppmw
$\mathrm{Ca}<125 \mathrm{ppmw}$
Co $<25 \mathrm{ppmw}$
$\mathrm{Cr}<25 \mathrm{ppmw}$
$\mathrm{Fe}<50 \mathrm{ppmw}$
$\mathrm{Mn}<25 \mathrm{ppmw}$
$\mathrm{Ni}<25 \mathrm{ppmw}$
$\mathrm{Ti}+\mathrm{V}<50 \mathrm{ppmw}$

B. Water

Water purity shall meet either of the following limits (derived from ASTM D1193-06

Type III reagent water):

Conductivity $\leq 0.25 \mu \mathrm{S} / \mathrm{cm}$

or

Resistivity $\quad \geq 4 \mathrm{M} \Omega \cdot \mathrm{cm}$

\subsection{Carbonization and Heat Treatment}

A. Argon $^{\mathrm{ii}}$

Argon shall meet the following limits:

$$
\begin{array}{ll}
\mathrm{Ar} & \geq 99.995 \% \mathrm{v} / \mathrm{v} \\
\mathrm{O}_{2} & \leq 50 \mathrm{ppmv} \\
\mathrm{H}_{2} \mathrm{O} & \leq 23.6 \mathrm{ppmv}\left(\text { or } \leq-54^{\circ} \mathrm{C} \text { dew pt. }\right)
\end{array}
$$




\begin{tabular}{|c|lll|}
\hline AGR-5/6/7 FUEL FABRICATION & Identifier: & SPC-1363 & \\
FEEDSTOCK CHEMICAL PURITY & Revision: & 5 & \\
SPECIFICATION & Effective Date: & $03 / 14 / 2017$ & Page: 7 of 12 \\
\hline
\end{tabular}

\section{PART 3 CHEMICAL PURITY VERIFICATION AND EXCEPTIONS}

\subsection{Chemical Certifications}

All chemicals that directly affect product properties or product quality shall be chemically/physically analyzed and verified with a certificate of conformance or a certificate of analysis. Vendor certifications are acceptable and should be supplemented, as necessary, to show compliance with all specifications for each chemical used.

Exception: It may be impractical to form compacts and analyze the matrix for compliance of impurities to the fuel specification for compacts (SPC-1352) before the resinated graphite powder is accepted for fuel fabrication. Resinated graphite powder may be analyzed for the elements of interest with application of conservative decontamination factors to estimate residual quantities of the impurities and give some assurance that the final compacts will comply with the fuel impurity specification (ECAR-3568).

\subsection{Sampling and Analysis}

Sampling and analysis shall be performed prior to using a chemical for fuel manufacturing either by the vendor or by the fuel manufacturer. The fuel manufacturer may be asked to confirm chemical purities if anomalous fuel properties bring chemical purity into question.

\subsection{Quality Control}

Purity requirements are considered by process because of the potential impact of each impurity differs by the process and/or stage of fuel fabrication. Some impurities have a potential to become incorporated into and retained within the fuel. These may affect in-pile fuel performance and integrity. The bases for these impurities are derived from their source contribution to final fuel compact impurity level. The compact impurity level is superior to the individual process-specific specifications above. Allowances may be given for noncompliant chemicals in individual processes if other sources for contaminants are sufficiently low that the compact impurity specifications will not be challenged.

In instances, such as with argon, which will likely involve multiple deliveries to a bulk supply tank, compliance with the specification can be demonstrated by showing that individual deliveries were compliant with the specifications. It is expected that the fuel manufacturer, BWX Technologies (BWXT), will verify that received gases meet these specifications prior to use or alert INL of the receipt of noncompliant gases so that the consequences can be assessed prior to its use in manufacture of Advanced Gas Reactor (AGR) experimental fuel. Chemicals that do not comply with given specifications will be evaluated on a case-by-case basis before the chemical is accepted for its intended use.

\section{PART 4 REFERENCES}

"Basis for NP-MHTGR Tritium Target Fabrication Feedstock Specifications," NPR-MHTGR-0496, September 25, 1992.

"NP-MHTGR Tritium Target Manufacture Raw Materials Specification,” NPR-MHTGR-0495, September 25, 1992.

ECAR-3568, "Maximum Impurity Guidance for AGR Resinated Graphite Matrix Powder," Rev. 0, February 2017.

GA-10600, “FSV Fuel Specification”, GA Technologies Inc., February 23, 1985.

SPC-1352, “AGR-5/6/7 Fuel Specification,” Rev 8, March 2017. 
Idaho National Laboratory

\begin{tabular}{|c|lll|}
\hline AGR-5/6/7 FUEL FABRICATION & Identifier: & SPC-1363 \\
FEEDSTOCK CHEMICAL PURITY & Revision: & 5 & Page: 8 of 12 \\
SPECIFICATION & Effective Date: & $03 / 14 / 2017$ & \\
\hline
\end{tabular}

\section{PART 5 SPECIFICATION BASIS}

\subsection{Historical Gas Specifications}

\begin{tabular}{|c|c|c|c|}
\hline & $\begin{array}{c}\text { NPR MHTGR } \\
\text { (NPR-MHTGR-0495; } \\
\text { NPR-MHTGR-0496) }\end{array}$ & $\begin{array}{c}\text { FSV General Atomics } \\
\text { (GA-10600) }\end{array}$ & $\begin{array}{c}\text { AGR-2 Babcock \& } \\
\text { Wilcox } \\
\text { (vendor certificates) }\end{array}$ \\
\hline \multicolumn{4}{|l|}{ Acetylene } \\
\hline Acetylene & $\geq 99.5 \%$ & $\geq 99.6 \%$ (99.7\% avg) & $\geq 99.6 \%$ \\
\hline Air & & & $\leq 0.40 \%$ \\
\hline \multicolumn{4}{|l|}{$\mathrm{H}_{2} \mathrm{O}$} \\
\hline $\mathrm{H}_{2} \mathrm{~S}$ & $\leq 50 \mathrm{ppm}$ & & $<10 \mathrm{ppm} \mathrm{S}$ \\
\hline $\mathrm{PH}_{3}+\mathrm{AsH}_{3}$ & $\leq 50 \mathrm{ppm}$ each & & $<15 \mathrm{ppm} \mathrm{PH}_{3}$ \\
\hline Dew pt. & & $-51^{\circ} \mathrm{C}$ & \\
\hline \multicolumn{4}{|l|}{ Argon } \\
\hline $\mathrm{Ar}$ & $\geq 99.996 \%$ & $\geq 99.998 \%$ & $\geq 99.995 \%$ \\
\hline $\mathrm{H}_{2}$ & & & $\leq 50 \mathrm{ppm}$ \\
\hline $\mathrm{H}_{2} \mathrm{O}$ & & & $\leq 23.6 \mathrm{ppm}$ \\
\hline $\mathrm{N}_{2}$ & & & $\leq 50 \mathrm{ppm}$ \\
\hline $\mathrm{O}_{2}$ & & & $\leq 50 \mathrm{ppm}$ \\
\hline Dew pt. & & & $\leq-65^{\circ} \mathrm{F}$ \\
\hline \multicolumn{4}{|l|}{ Hydrogen } \\
\hline $\mathrm{H}_{2}$ & $\geq 99.985 \%$ & $\geq 99.98 \%$ & $\geq 99.95 \%$ \\
\hline \multicolumn{4}{|l|}{$\mathrm{CO}_{2}$} \\
\hline $\mathrm{H}_{2} \mathrm{O}$ & \multirow[t]{2}{*}{$\Sigma \leq 25 \mathrm{ppm}$} & & $\leq 7.8 \mathrm{ppm}$ \\
\hline $\mathrm{O}_{2}$ & & & $\leq 10 \mathrm{ppm}$ \\
\hline Dew pt. & & & $\leq-80.0^{\circ} \mathrm{F}$ \\
\hline \multicolumn{4}{|c|}{ Methyltrichlorosilane (MTS) } \\
\hline $\mathrm{CH}_{3} \mathrm{SiCl}_{3}$ & $\geq 97.0 \%$ & $\geq 97.0 \%$ & $\geq 98.5 \%$ \\
\hline $\mathrm{THC}$ & $1.0 \%$ & & \\
\hline $\mathrm{Fe}$ & $\leq 10 \mathrm{ppm}$ & $\leq 10 \mathrm{ppm}$ & \\
\hline $\mathrm{Ni}$ & $\leq 10 \mathrm{ppm}$ & & \\
\hline $\mathrm{Cr}$ & $\leq 10 \mathrm{ppm}$ & & \\
\hline Sp.G.@25ㄷ & $1.26 \pm 0.02 \mathrm{~g} / \mathrm{cc}$ & $1.26 \pm 0.02 \mathrm{~g} / \mathrm{cc}$ & \\
\hline Color & & & colorless \\
\hline IR Spectrum & & & conforms \\
\hline
\end{tabular}


Idaho National Laboratory

\begin{tabular}{|c|lll|}
\hline AGR-5/6/7 FUEL FABRICATION & Identifier: & SPC-1363 & \\
FEEDSTOCK CHEMICAL PURITY & Revision: & 5 & \\
SPECIFICATION & Effective Date: & $03 / 14 / 2017$ & Page: 9 of 12 \\
\hline
\end{tabular}

Historical Gas Specifications (continued).

\begin{tabular}{|c|c|c|c|}
\hline & $\begin{array}{c}\text { NPR MHTGR } \\
\text { (NPR-MHTGR-0495; } \\
\text { NPR-MHTGR-0496) }\end{array}$ & $\begin{array}{c}\text { FSV General Atomics } \\
(\text { GA-10600) }\end{array}$ & $\begin{array}{c}\text { AGR-2 Babcock \& } \\
\text { Wilcox } \\
\text { (vendor certificates) }\end{array}$ \\
\hline \multicolumn{4}{|l|}{ Propylene } \\
\hline Grade & Polymer & Polymer & Polymer \\
\hline Propylene & $\geq 99.0 \%$ & $\geq 95.0 \%$ & $\geq 99.5 \%$ \\
\hline Ethane & & & $<50 \mathrm{ppm}$ \\
\hline Propane & & & $<4000 \mathrm{ppm}$ \\
\hline Iso-Butane & & & $<100 \mathrm{ppm}$ \\
\hline n-Butane & & & $<100 \mathrm{ppm}$ \\
\hline$\Sigma\left(\mathrm{H}_{2} \mathrm{O}, \mathrm{O}_{2}\right)$ & & $\leq 1.5 \% \mathrm{v} / \mathrm{v}\left(\mathrm{C}_{3} \mathrm{H}_{6}\right.$ basis $)$ & \\
\hline$\Sigma\left(\mathrm{H}_{2} \mathrm{O}, \mathrm{O}_{2}, \mathrm{CO}_{2}\right)$ & $\leq 150 \mathrm{ppmv}$ & & \\
\hline Total S & $\leq 10 \mathrm{ppmv}$ & & \\
\hline
\end{tabular}

\subsection{Rationale for Gas Purities}

The gas purities are tied to industrial standards, when available, to facilitate consistent and reliable availability. Any addition to or deviation from standards needs to be justified on a case-by-case basis. Consideration was given to the instances where each gas is used in establishing the specifications. Not all impurities stated in the standards for any given gas grade are detrimental to the fuel fabrication process. Those impurities, having no identified significant adverse or beneficial impact on the product, have been excluded in the specifications. Water impurity in the gases may be reported either as the concentration or by the equivalent dew point at standard atmospheric pressure.

\subsubsection{Acetylene}

Historical acetylene concentrations are largely consistent with the CGA G-1.1 standard for Grade H acetylene. Lesser grades have much less acetylene and substantially higher phosphine and hydrogen sulfide allowances; none of which is desirable in the feedstock. Grade $\mathrm{H}$ is the grade used for atomic absorption analysis. The specified values are given on a solvent free basis because the amount of solvent carried over into the acetylene is a function of tank levels and tank depletion rates. Acceptable levels of phosphine and sulfide in the coating process have not been determined. 


\begin{tabular}{|c|lll|}
\hline AGR-5/6/7 FUEL FABRICATION & Identifier: & SPC-1363 & \\
FEEDSTOCK CHEMICAL PURITY & Revision: & 5 & \\
SPECIFICATION & Effective Date: & $03 / 14 / 2017$ & Page: 10 of 12 \\
\hline
\end{tabular}

\subsubsection{Argon}

Historical argon specifications have focused primarily on the argon concentration and ignored impurities, which have been low due to the high purity of the argon in use. This is partially due to the exclusive use of argon, historically, during the deposition of the buffer and pyrolytic carbon layers. Carbon dioxide, oxygen, and water would react with carbon at process temperatures to form carbon monoxide, but the excess of carbon soot during buffer and pyrocarbon deposition prevents this reaction from being a concern. AGR flow sheets now include approximately $30 \% \mathrm{v} / \mathrm{v}$ argon in the fluidizing gas used for the deposition of silicon carbide. The oxygen donors will react with carbon liberated from the MTS and skew the [Si]:[C] ratio during $\mathrm{SiC}$ deposition, which may impact $\mathrm{SiC}$ layer density, tensile strength, grain size, and retentiveness for fission products. The concentration of oxygen donors $\left(\mathrm{H}_{2} \mathrm{O}, \mathrm{O}_{2}\right.$, and $\left.\mathrm{CO}_{2}\right)$ needs to be kept low, but acceptable levels have not been quantified.

Hydrocarbon content in the argon gas standards is very low relative to the oxygen donors. No credit is taken for hydrocarbon content in reducing oxygen availability.

Argon is also used as a sweep gas during the carbonization of the phenolic resin binder in the fuel compacts. The purity levels were selected to protect the compacts, graphite boats, and furnace internals from oxidation. No analyses have been done to determine acceptable levels of impurities during carbonization.

\subsubsection{Carbon Monoxide}

Carbon monoxide (CO) is used during heat treatment of fuel kernels to minimize carbon losses in the kernel resulting from carbothermal reduction of uranium oxides. Oxygen, water, or carbon dioxide will react with carbon and carbides to form $\mathrm{CO}$ and deplete carbon in the kernels. No credit is taken for hydrocarbon impurities in the CO that will scavenge the oxidizers and protect the carbon in the fuel. An acceptable oxidizing potential has not been determined for carbothermic reduction.

Nitrogen has an unevaluated potential to react with uranium carbides to form nitrides at sintering temperatures. The specified maximum is arbitrary, but readily achievable at the specified carbon monoxide purity.

\subsubsection{Hydrogen}

The concentration of CGA-5.3 Grade D hydrogen is comparable to historical hydrogen specifications with (generally) reduced levels of contaminants, especially $\mathrm{CO}_{2}, \mathrm{O}_{2}, \mathrm{H}_{2} \mathrm{O}$, and $\mathrm{CH}_{4}$. The oxygenated compounds can lead to attack of the carbon in the kernels during calcination and sintering or to IPyC layer erosion just prior to and during the early stages of $\mathrm{SiC}$ deposition. Excessive oxidizing potential may skew the [Si]:[C] ratio in the $\mathrm{SiC}$ sufficiently to impact $\mathrm{SiC}$ grain structure, density, tensile strength, and the ability to retain or retard fission product diffusion.

Low moisture content of the hydrogen is beneficial in its use as a sweep gas for the methyltrichlorosilane (MTS) vaporizer whereas moisture reacts with the MTS to form hydrochloric acid and silicon polymers.

Grade D has substantially lower impurity levels than Grade B (roughly by an order of magnitude), but not much higher impurity levels than purer grades. Grade D should be readily available given that it is commonly used as fuel and for hydrogenation. 


\begin{tabular}{|c|lll|}
\hline AGR-5/6/7 FUEL FABRICATION & Identifier: & SPC-1363 & \\
FEEDSTOCK CHEMICAL PURITY & Revision: & 5 & \\
SPECIFICATION & Effective Date: & $03 / 14 / 2017$ & Page: 11 of 12 \\
\hline
\end{tabular}

\subsubsection{Propylene}

Historical propylene specifications have been for polymer grade, but significant variability is noted in the propylene concentration (95-99.5\%). Whereas the propylene is used exclusively for pyrolytic carbon deposition and the inlet concentration is less than $15 \%$ of the total gas flow (accounting for dilution with auxiliary argon gas flow through the annular orifice surrounding the distributor nozzle); impurities are not expected to have a significant impact. Other hydrocarbons, comprising the majority of the impurities, will decompose and contribute to the carbon deposition, so no specification is given for the other hydrocarbons. However, water, oxygen, and carbon dioxide will react readily with decomposition products. The plethora of carbon soot particles in the coater is sufficient to react with available oxygen. No limit is imposed on oxygen-bearing compounds until it is determined to be detrimental to layer density or isotropy.

\subsection{Rationale for Liquid Purity}

Industrial purity standards, when available and practical for use, are invoked in the liquid purity specifications. Those impurities having no identified significant adverse or beneficial impact on the product have been excluded in the specifications. Any addition to or deviation from standard impurity levels need to be justified on a case-by-case basis.

\subsubsection{Methyltrichlorsilane (MTS)}

MTS purity may be affected by the materials wetted by the MTS during production, storage, or conveyance from the storage bottle to the process. MTS may have some level of free chlorine or $\mathrm{HCl}$ present that could react with stainless steel or other surfaces, especially at the elevated temperatures when the MTS is evaporated. The present configuration at BWXT Nuclear Operations Group, Inc. for MTS delivery includes stainless steel transfer lines, a mass flow controller with wetted stainless steel components, and a Brooks Turbo Vaporizer with 316 stainless steel wetted parts.

Specifications for transition metal contamination of the MTS have not been given because we have not observed extensive corrosion of the stainless steel and the dominant transition metals ( $\mathrm{Fe}, \mathrm{Ni}$, and $\mathrm{Cr}$ ) chlorides have boiling or decomposition temperatures well in excess of the operating temperature for the vaporizer. Contamination would tend to collect in the vaporizer rather than being gasified and transported to the coater. One exception is chromyl chloride, $\mathrm{CrO}_{2} \mathrm{Cl}_{2}$. Should chromyl chloride form during the corrosion of stainless steel and not be reduced by the hydrogen, then it would have a substantial vapor pressure at the Turbo Vaporizer operating temperature (b.p. $=117^{\circ} \mathrm{C}$ ) and be swept into the coater where it would form a chromium carbide that would co-deposit with silicon carbide ( $\mathrm{SiC}$ ). The presence of chromium carbide in the $\mathrm{SiC}$ lattice may result in superstoichiometric $\mathrm{Si}$ and/or grain-growth interruptions at the deposition site with unquantified impacts on fission product diffusivities within the $\mathrm{SiC}$ layer.

Although hydrocarbon impurities in the MTS can skew the [Si]:[C] stoichiometry and impact the SiC layer properties, no specification is given due to the inability of the MTS supplier and the fuel manufacturer to quantify hydrocarbon impurities in the MTS.

\subsubsection{Water}

Water used in the uranium broth must have a high purity level because of the detrimental effects of dissolved metal salts in the performance of the uranium kernels. Water is readily purified to remove cationic and anionic species. Residual halides in the green kernels would cause a quantity of the uranium to volatilize in the sintering furnace and re-condense in the process off-gas systems. 


\begin{tabular}{|c|lll|}
\hline AGR-5/6/7 FUEL FABRICATION & Identifier: & SPC-1363 & \\
FEEDSTOCK CHEMICAL PURITY & Revision: & 5 & \\
SPECIFICATION & Effective Date: & $03 / 14 / 2017$ & Page: 12 of 12 \\
\hline
\end{tabular}

Water used for the overcoating process needs to be low in dissolved metals to meet the purity specifications for the fuel compacts. The presence of some chlorine in the water could facilitate volatilization of metal contaminants during heat treatment of the compacts. Water used for overcoating may have more impurities than water used for fuel kernel forming.

a. For an industrial very high temperature reactor (VHTR) fuel fabrication facility, it is recommended that future hydrogen supply specifications adopt the limits listed below (derived from CGA G-5.3 (R2004) Grade D hydrogen). BWXT specifications are given in these chemical specifications because the hydrogen supply serves multiple fuel fabrication processes. Vendor certificates generally show, by impurity levels, that the received hydrogen complies with CGA G-5.3 (R2004) Grade D specifications.

$\mathrm{H}_{2} \geq 99.99 \% \mathrm{v} / \mathrm{v}$

$\mathrm{H}_{2} \mathrm{O} \leq 3.5$ ppmv (or $\leq-68.3^{\circ} \mathrm{C}$ dew pt.)

$\mathrm{O}_{2} \quad \leq 5 \mathrm{ppmv}$

b. For an industrial VHTR fuel fabrication facility, it is recommended that future argon supply specifications adopt the limits listed below (derived from CGA G-11.1 (R2004) Grade C argon). Air Products specifications for argon, oxygen, and moisture content are given in these chemical specifications, which is the vendor for BWXT argon, because the BWXT argon supply serves multiple fuel fabrication processes. Vendor certificates generally show that the received argon complies with CGA G-11.1 (R2004) Grade C specifications.
Ar $\geq 99.997 \% \mathrm{v} / \mathrm{v}$
$\mathrm{O}_{2} \quad \leq 5 \mathrm{ppmv}$
$\mathrm{H}_{2} \mathrm{O} \leq 10.5$ ppmv (or $\leq-60.0^{\circ} \mathrm{C}$ dew pt.) 